\title{
DOSE-DEPENDENT BIFURCATION ANALYSIS OF PLASMA RENIN ACTIVITY AFTER NICARDIPINE TREATMENT
}

\author{
Kaloyan Yankov \\ Faculty of Technics and Technologies, Trakia University, Bulgaria \\ 38 Graf Ignatiev str., 8600 Yambol, Bulgaria \\ e-mail: kaloyan.yankov@trakia-uni.bg
}

\begin{abstract}
Renin-angiotensin system is one of the general regulatory mechanisms of blood pressure. The activity of the system depends on the rate of renin secretion, therefore, plasma renin activity (PRA) is one of the main variables that mediates the effect of a number of factors on blood pressure. Consequently, the impact of a particular drug on blood pressure disorders can be evaluated by the PRA changes. In clinical practice, the administered therapeutic dose is of critical nature, and a number of methods are known for its calculation. In the present study, applying bifurcation analysis the range of the administered doses of the nicardipine (antihypertensive drug) are determined. The bifurcation diagrams show how the stability of the renin-angiotensin system depends on the administered dose.
\end{abstract}

Keywords: Bifurcation, Phase Plane, Plasma renin activity, Stability analysis, Modeling.

"That which is static and repetitive is boring. That which is dynamic and random is confusing. In between lies art." John A. Locke (1632-1704), British philosopher and medical researcher

\section{INTRODUCTION}

The regulation of blood pressure in the body is carried out by the renin-angiotensin system. The criterion for its action is plasma renin activity (PRA). The effect of a particular drug on blood pressure abnormalities can be evaluated by monitoring the change in PRA. Therefore, one of the approaches to drug regulation of blood pressure is the impact on PRA. This can be done by administering various drugs: calmodulin inhibitors [2], prostaglandin synthase blockers [4], angiotensin-converting enzyme inhibitors [5] and calcium channel blockers [8]. In all cases, the dosage of the drug is important $[9,10]$. A significant problem with medication administration is to investigate how the stability of the physiological system is affected by the drug. When the reaction depends on a parameter, in this case, the dose administered, it is advisable to determine critical values for that parameter at which the system would dramatically change its behavior. Bifurcation analysis shows the behavior of a system as a function of a selected parameter [1].

In the present work with the means of bifurcation analysis, the critical limits of the administered doses of the preparation nicardipine are determined. The bifurcation diagrams show how the stability of the renin-angiotensin system depends on a given parameter, in this case, the dose administered. Predicting the required dose of the drug makes it possible to avoid the side effects of the body.

\section{MATHEMATICAL MODEL}

The subject of analysis is a change in the activity of plasma renin activity after treatment with nicardipine in experimental animals $[3,6]$. The mathematical model of the process in function 


\section{IRTTIE}

Ipplied Reserer rhes in Technics, Technologies and Bduration

Journal of the Faculty of Technics and Technologies, Trakia University https://sites.google.com/a/trakia-uni.bg/artte/

of the drug dose is presented in [7]. The dose-dependent model of the regulation kinetics in the state space is:

$$
\left\|\begin{array}{c}
\frac{d x_{1}(t, d)}{d t} \\
\frac{d x_{2}(t, d)}{d t}
\end{array}\right\|=\left\|\begin{array}{cc}
0 & 1 \\
-\omega_{0}^{2} & -2 . \zeta(d) \cdot \omega_{0}
\end{array}\right\| \cdot\left\|\begin{array}{c}
x_{1}(t, d)-x_{O 1} \\
x_{2}(t, d)-x_{O 2}
\end{array}\right\|+\left\|\begin{array}{c}
0 \\
-K_{0}(d)
\end{array}\right\|
$$

The initial conditions are:

$$
\begin{aligned}
& x_{01}=7.58 \\
& x_{02}=0
\end{aligned}
$$

$$
\text { where: } \mid \begin{aligned}
& x_{1}(t, d), x_{2}(t, d)-\text { the state of the system } ; \\
& \boldsymbol{d} \text { - the applied dose }[\mathrm{mg} / \mathrm{kg}] \\
& \zeta(d)=4-e^{-\frac{d+73,9}{123,4}}-\text { the damping ratio; } \\
& \omega_{0}=0,64-\text { the natural frequency of the process; } \\
& K_{0}(d)=3,64 \cdot \ln (d)-14,47 \text { - the base level }
\end{aligned}
$$

\section{STABILITY ANALYSIS}

The stability of the system is determined by the state space matrix $\boldsymbol{A}$ :

$$
A=\left\|\begin{array}{cc}
0 & 1 \\
-\omega_{0}^{2} & -2 . \zeta(d) \cdot \omega_{0}
\end{array}\right\|
$$

From the characteristic equation:

$$
\operatorname{det}(A-\lambda . I)=\left\|\begin{array}{cc}
-\lambda & 1 \\
-\omega_{0}^{2} & -2 . \zeta(d) \cdot \omega_{0}-\lambda
\end{array}\right\|
$$

the eigenvalues of $\lambda$ are determined. The solutions are:

$$
\lambda_{1,2}=-\zeta(d) \cdot \omega_{0} \pm \omega_{0} \cdot \sqrt{\zeta^{2}(d)-1}
$$

The eigenvalues depend on the applied dose $\boldsymbol{d}$ by the damping ratio $\zeta$. Substituting $\zeta$ by its equivalent expression yields:

$$
\lambda_{1,2}=-\left(4-e^{-\frac{d+73,9}{123,4}}\right) \cdot \omega_{0} \pm \omega_{0} \cdot \sqrt{3-e^{-\frac{d+73,9}{123,4}}}=r(d) \pm i . m(d)
$$




\section{IRTTE} Ipplied Resseirlohes in Technics, Technologies and Eductition Journal of the Faculty of Technics and Technologies, Trakia University https://sites.google.com/a/trakia-uni.bg/artte/

Real part:

$$
r(d)=-\left(4-e^{-\frac{d+73,9}{123,4}}\right)
$$

Potentially imaginary part:

$$
m(d)=\sqrt{3-e^{-\frac{d+73,9}{123,4}}}
$$

\subsection{Appreciation of the discriminant}

The presence of an imaginary ingredient in the root determines the occurrence of oscillations in the process. The discriminant is:

$$
D(d)=3-e^{-\frac{d+73.9}{123.4}}
$$

The graphical dependence of the discriminant on the dose is in Figure 1. In order to be negative, the dose $\boldsymbol{d}$ must fulfill the inequality:

$$
d<123,43 \cdot \ln \left(\frac{1}{3}\right)-73 \cdot 9=-209,469
$$

Presumably, the dose is a positive number, and therefore the discriminant is always positive, which precludes obtaining complex solutions regardless of the dose.

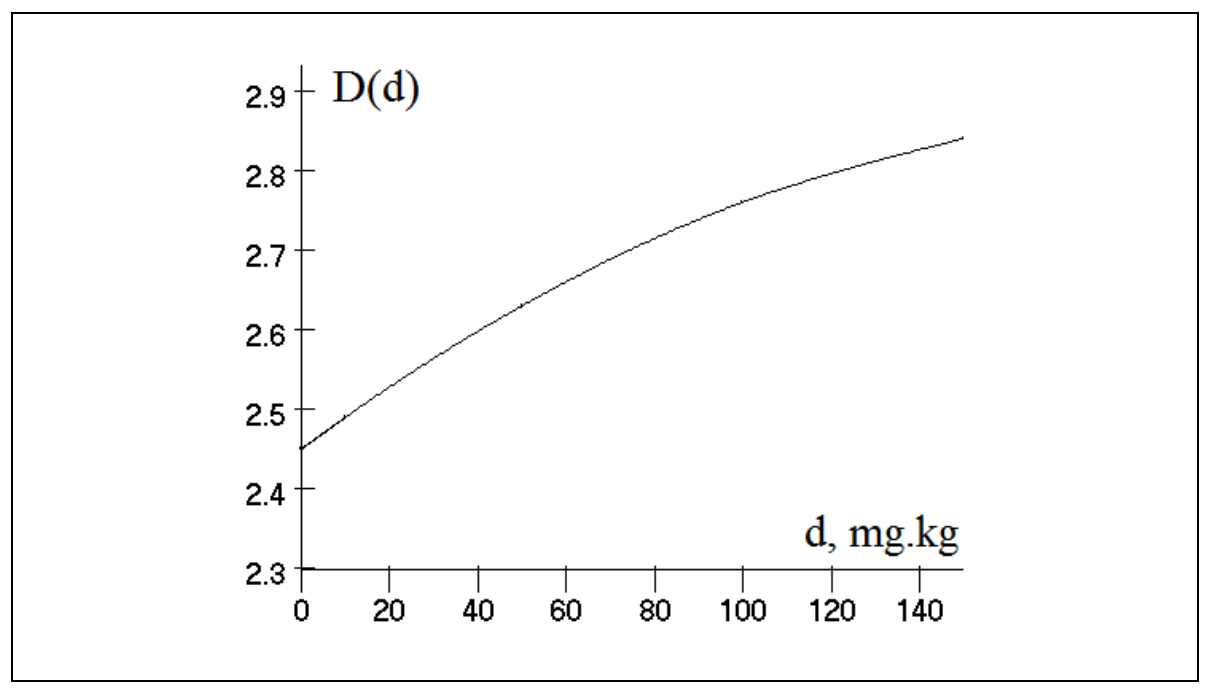

Figure 1.

Dependence of the discriminant on the administered dose

IRITIE Vol. 7, No. 3, 2019 ISSN 1314-8788 (print), ISSN 1314-8796 (online), doi: 10.15547/artte.2019.03.003 


\section{IRTIIE} Ipplied Researreches in Technics, Technologies and Eductation Journal of the Faculty of Technics and Technologies, Trakia University https://sites.google.com/a/trakia-uni.bg/artte/

\subsection{Appreciation of the real roots}

The absence of an imaginary part in the solutions determines the following two real values:

$$
\mid \begin{aligned}
& \lambda_{1}=-\left(4-e^{-\frac{d+73,9}{123,4}}\right) \cdot 0,64+0,64 \cdot \sqrt{3-e^{-\frac{d+73,9}{123,4}}} \\
& \lambda_{2}=-\left(4-e^{-\frac{d+73,9}{123,4}}\right) \cdot 0,64-0,64 \cdot \sqrt{3-e^{-\frac{d+73,9}{123,4}}}
\end{aligned}
$$

Figure 2 shows their variation in dose function.

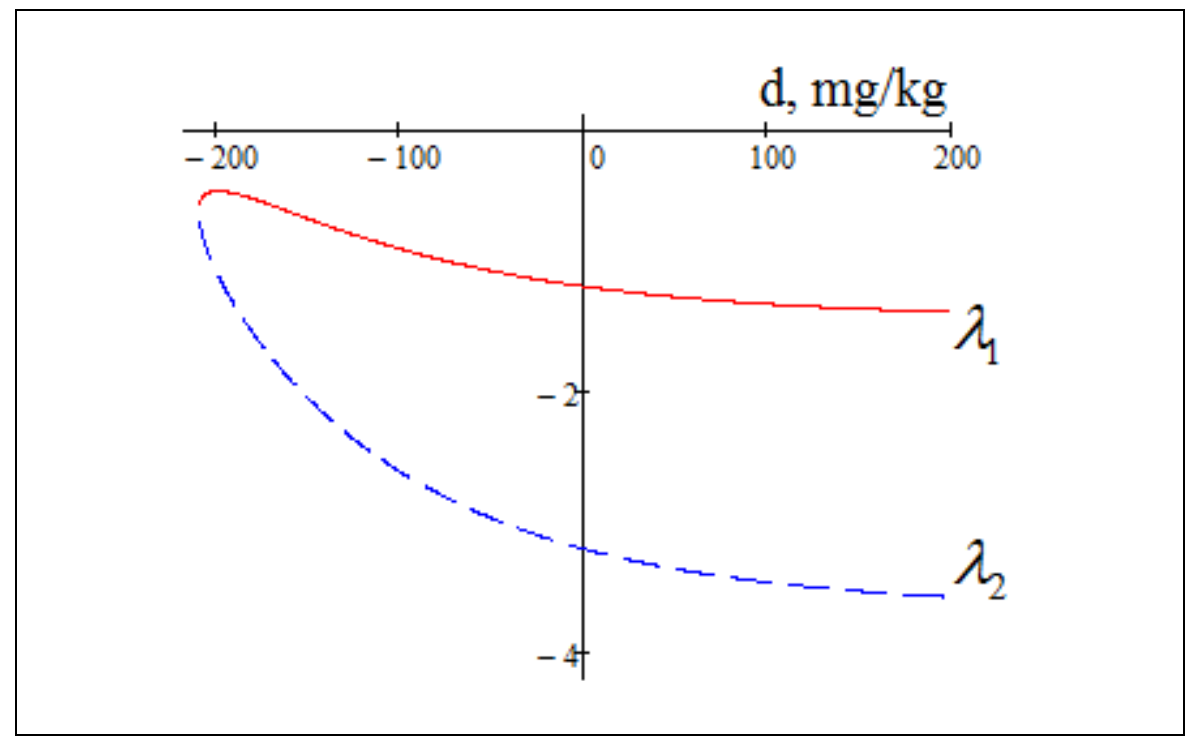

Figure 2.

Dependence of the eigenvalues on the administered dose

The limit to an infinitely large dose again leads to negative values:

$$
\mid \begin{gathered}
\lim \left(\lambda_{1}(d)\right)=-1.45 \\
d \rightarrow \infty \\
\lim \left(\lambda_{2}(d)\right)=-3.67 \\
d \rightarrow \infty
\end{gathered}
$$

The results show that the process is stable regardless of the dose administered. The conclusion obtained by the phase plane method [11] is confirmed.

\section{CONCLUSION}

In the present work, the stability of the renin-angiotensin system to different doses of nicardipine was investigated. The analysis is made on the mathematical model of PRA change, which is an indicator of PAC behavior. Using bifurcation analysis, critical doses that

IRTTE Vol. 7, No. 3, 2019 ISSN 1314-8788 (print), ISSN 1314-8796 (online), doi: 10.15547/artte.2019.03.003 


\section{ARTTIE $Y$}

Ipplied Resseirlores in Technics, Technologies and Educration

Journal of the Faculty of Technics and Technologies, Trakia University https://sites.google.com/a/trakia-uni.bg/artte/

would influence the sustainable behavior of PAC are sought. Analytical expressions and graphs show that such points do not exist.

The final conclusion of the study is that administration of nicardipine at random doses cannot induce instability reactions on the system.

\section{ACKNOWLEDGMENTS}

This study was supported by Grant 2.ФTT/31.03.2017, „Investigation of systems and processes by the phase plane method" from the Faculty of Technics and Technologies of Yambol, Trakia University, Bulgaria.

The author expresses his gratitude to Prof. A.Tolekova, Ph.D., Trakia University, Faculty of Medicine, Bulgaria for the captopril data provided.

\section{REFERENCES}

[1] Hale J.K., \& Kocak H. (1991). Dynamics_and_Bifurcations. Springer Verlag, New York.

[2] Ilieva, G., \& Trifonova, K., \& Tolekova, A., \& Logofetov, A. (1994). Plasma renin activity in tachistin-stimulated hypercalcemia and under the effect of chlorazine. Eksp Med Morfol, 1994, XXXII (3-4): 1-7.

[3] Ilieva, G., \& Tolekova A., \& Parvanova A. (1996). The changes of RAAS and electrolyte balance in inhibition of voltage-gated calcium channels and angiotensin-converting enzyme. Proc. 7th International conference "Modern tendencies in the development of fundamental and applied sciences", 6-7 june, Stara Zagora, Bulgaria. pp.259-264.

[4] Tolekova, A., \& Ilieva, G., \& Tzaneva, M., \& Ganeva, M. (1995). Effect of Acute and Chronic Acetylsalicylic Acid Administration on Renin-Angiotensin-Aldosterone System and Stomach Mucosa in Rats. Endocrine Regulations, Bratislava, 29(2): pp.115-120.

[5] Tolekova, A. \& llieva, G., \& Parvanova, A. (1996). Comparison of the effects on RAAS of the combination of ACE inhibition with calcium channel blockade. IMAB Annual proceedings (scientific papers), 1996, V. 2(1), pp.209-210.

[6] Tolekova, A. (1998). Functional analysis of PRA changes after some pharmacological influences. Proceedings of Jubilee conference " 50 Years UBS-Plovdiv", v. II, pp.53-56.

[7] Tolekova, A., \& Yankov K. (2006) Model of a plasma renin activity after nicardipine treatment. Journal of Information, Control and Management Systems, Vol. 4, No 2, Slovakia, pp.203-212.

[8] Yankov, K., \& Tolekova, A., \& Spasov, V. (1998). Mathematical modelling of druginduced changes in plasma renin activity, Pharmacia, 1998, Vol. 45 (1), pp.26-29.

[9] Yankov K. Dose-Effect Modeling of Experimental Data. (2010). Journal of Information, Control and Management Systems, Vol. 8(3), 2010, pp.257-264.

[10] Yankov, K., Identification of Effective Doses in Binary Mixtures. (2014). Proc. Int. Conference on Information Technologies (InfoTech-2014). St. Constantine and Elena resort, Bulgaria, sept.18-20, 2014, pp.316-324.

[11] Yankov K., Phase-Plane Models in Korelia Software. (2018). Proc. 32th Int. Conference on Information Technologies (InfoTech-2018), IEEE Conference Rec. No. 46116. 20-21 Sept. 2018, St. St. Constantine and Elena, Bulgaria. pp.131-140. 